\title{
Lupane-Type Triterpenoids and Sterol from Zizyphus Spina Christi Grown in Sudan
}

\author{
NAWAL MOHAMED IBRAHIM ELNAGAR ${ }^{\star 1,2}$ and BARAKAT MOHAMMED MODAWI ${ }^{3}$ \\ ${ }^{1}$ Chemistry Department, Faculty of Education, University of Kordofan.Sudan. \\ ${ }^{2}$ Chemistry Department, Faculty of Science, University of Hafr Albatin, Saudi Arabia. \\ ${ }^{3}$ Chemistry Department, Faculty of Science, University of Khartoum.Sudan. \\ ${ }^{*}$ Corresponding author E-mail: nawalelnagar@yahoo.co.uk \\ http://dx.doi.org/10.13005/ojc/320215
}

(Received: December 07, 2015; Accepted: January 16, 2016)

\section{ABSTRACT}

The fine powder of the shade-dried root bark of Zizyphus spina Christi [Rhamnaceae] was exhaustively extracted with aqueous ethanol at room temperature. Fractionation, isolation and purification were carried out with column chromatography. Characterization and identification of the isolated pure components were based on their spectroscopic data and comparison with data cited in literature. As a result four new compounds, three of them are lupane-type tritepenoids and the fourth compound is sterol were identified. These compounds are lupeol, betulinaldehyde, betulin and $\beta$-sitosterol.

Keywords: Zizyphus Spina Christi, Root Bark, Lupeol, Betulinaldehyde, $\beta$ - Sitosterol Betulin.

\section{INTRODUCTION}

Throughout human history, natural products have been widely used as remedies ${ }^{1-5}$ to cure and treat various illnesses. Humans are continuously learning more about the indispensible therapeutic properties of natural products as well as becoming conscious of the importance of a healthy life style-to gain life quality.

An impressive amount of natural substances has been high-lighted by the media ${ }^{3,6}$ due to their wideranging properties. Among these substances are the following lupane- type pentacyclic triterpenoids: Lupeol (1), a significant lupane- type pentacyclic triterpenoid is a common constituent of grape, bazel nut, olive oil, mango pulp and it was isolated from the stem bark of Cralaeva nurvalis ${ }^{6}$ [capparidacaea]. Lupeol was reported to be a constituent of the white part of birch bark [Betula papyfera] and red alder Alnus rubra ${ }^{7-9}$.

Lupeol exhibits a broad spectrum of biological activities ${ }^{7}$ and can be used as a chemopreventive substance to avoid several diseases. Betulinaldehyde (2) was isolated from many plant 
species $^{10}$ and it was the most intensively studied constituent of the birch bark triterpenoids because of its unique anti- cancer and anti HIV bioactivity ${ }^{11,12}$.

Betulinic acid (3) together with lupeol, betulinaldehyde and betulin were isolated from the stem bark of Tectona grandis ${ }^{10}$, Betulinic acid was also isolated from the root bark of $Z$. spina Christi. $^{13-16 .}$

Betulinic acid was synthesized from betulin by selective oxidation ${ }^{17}$. The reaction required the choice of the proper oxidizing reagent and conditions so that the oxidation reaction takes place predominantly at the primary C-28 hydroxyl group leaving the secondary hydroxyl group at C-3 in fact. Betulinic acid can then be easily obtained from the resulting betulinaldehyde.

Betulin(4), a pentacyclic triterpene was obtained for the first time in 1788 from birch bark [Betula papyfera] ${ }^{8}$ Betulin occurs in large amounts in the free form in the outer bark of white birch ${ }^{9}$ and it was isolated from alnus species, Trochoden dron, Vicia faba and many other plants ${ }^{18}$.

Since the 1970s, intensive and extensive research has been committed to explore more about the medicinal application of betulin and its derivatives, in particular in their anti-tumor and antiHIV biological activities ${ }^{19,20}$.

Betulin is commonly used in medicine, pharmaceutical, perfumes manufacturing and in food and chemical industries. ${ }^{21} \beta$-sitosterol (5) the

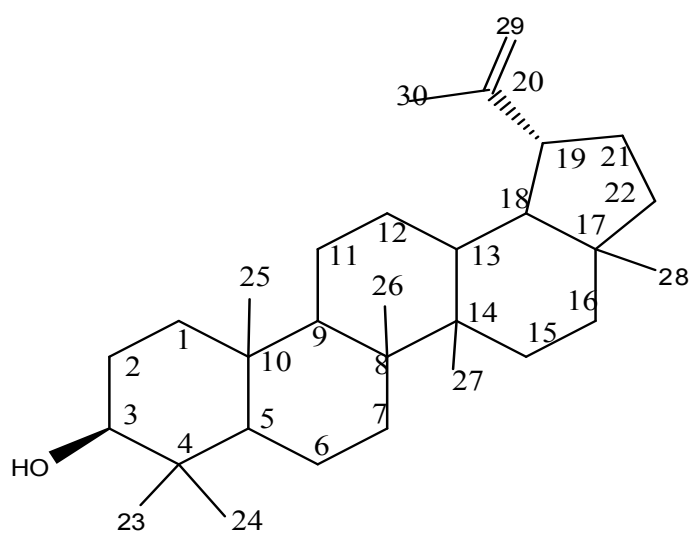

Scheme 1: Structure of compound 1 20(29)Iupen-3-OI (lupeol) commonest sterol of higher plants which is widely distributed in plants and also occurs in marine organisms. $^{22-22}$

$\beta$-sitosterol is an important anti-hyper cholesterol, an estrogenic and a hypolipidemic agent. It shows antibacterial and antifungal properties ${ }^{23-25}$.

\section{MATERIALS AND METHODS}

\section{The plant material}

The plant Z. spina Christi was collected from Kordofan area (Sudan) and identified by the Botany department, Faculty of science University of Khartoum. The root bark was carefully peeled, shade-dried and finally powdered.

\section{Chemicals}

The following either analytical grade or carefully purified and perfectly dried chemicals were used. Petroleum ether (pet.ether) $\left[60-80^{\circ} \mathrm{C}\right]$, ethanol, methanol, acetone, dichloromethane (DCM), silica gel for column chromatography [100-200 mesh], silica gel for thin-layer chromatography (TLC) GF254 and anhydrous sodium sulphate.

\section{Instruments}

The following spectroscopic techniques were used wherever needed:

1. Ultra Violet and Visible absorption Spectroscopy [UVIVis].

2. Infrared Spectroscopy [IR].

3. Mass Spectroscopy[ Electron- Impact Mass Spectrometry EI-MS].

4. Nuclear Magnetic Resonance Spectroscopy [NMR].

5. One Dimensional NMR Spectroscopy,

Proton Nuclear Magnetic Resonance[ $\left.{ }^{1} \mathrm{HNMR}\right]$, carbon-13 Nuclear Magnetic Resonance $\left[{ }^{13} \mathrm{CNMR}\right]$ and Destortionless Enhancement through Polarization Transfer [DEPT].

6. Two Dimensional NMR Spectroscopy, Proton Correlated Spectroscopy [COSY], Nuclear Over-houser Effect Spectroscopy [NOESY], Hetronuclear Single Quantum Coherence Spectroscopy [HSQC] and Hetronuclear Multiple bond Correlation Spectroscopy [HMBC]. 


\section{Extraction}

The fine-dried powder of the root bark of Z. spina christiwas exhaustly extracted with $80 \%$ ethanol for 72 hours at room temperature with frequent shaking. The aqueous ethanol extract was filtered through Watman No. 42 filter paper. The solvent was carefully removed, as completely as possible; under reduce pressure using a rotatory evaporator.

The wet crude residue was then dissolved in ethanol and perfectly dried with anhydrous sodium sulphate. The ethanol solution of the crude extract was filtered as before and then centrifuged. The solvent was carefully removed and a mean percentage yield of 28 was obtained.

\section{Column Chromatography}

A glass column $[120 \times 8 \mathrm{~cm}]$ well packed with silica gel [100- 200 mesh] in petroleum ether was used for the separation of the components of the crude extract. The crude residue was completely dissolved in ethanol and thoroughly mixed with silica gel. Ethanol was completely removed and the silica gel containing the crude extract was carefully packed on the top of the column.

The column was patiently eluted first with pet.ether followed by successive elution with [5:1], [2:3] and [1:3] pet.etherlDCM solvent mixtures. All fractions obtained from each of the above three successive elutions were carefully monitored with thin-layer chromatography and similar fractions from each successive elution were combined. Three, A,

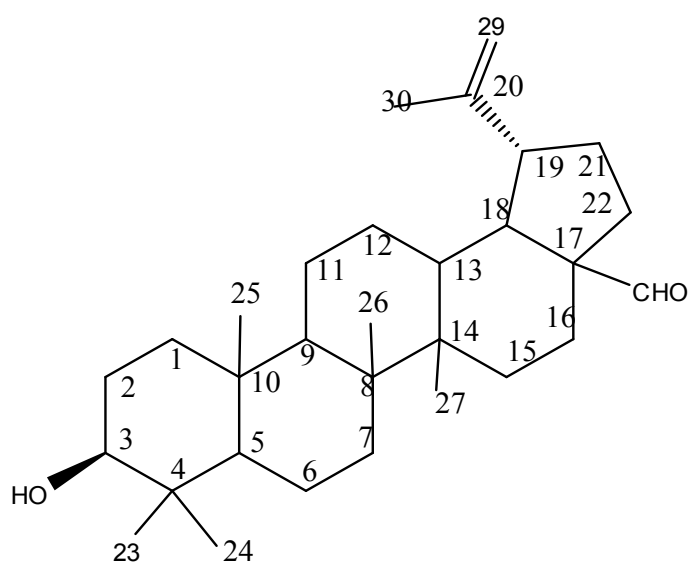

Scheme 2: Structure of compound 2 20(29)-lupen-3-ol -28-al (betulinaldehyde)
$B$ and $D$ combined fractions were obtained from the above successive elutions. Each of the combined fractions was perfectly dried and filtered. Careful removal of the solvent mixtures from each resulted in the formation of a yellow oily substance from $A$, a white grey solid from $B$ and a pale green sticky material from $D$.

\section{Isolation and purification of components}

A glass column [40 $\mathrm{x} 1 \mathrm{~cm}$ ], packed with the same silica gel in pet.ether was used for the separation of the components of the yellow oily substance. The crude substance was dissolved in ethanol and thoroughly mixed with silica gel. After complete removal of ethanol the silica gel containing fraction A was carefully packed on the top of the column.

The column was eluted first with pet. ether acetone [9:1] and finally with pet. etherlacetone[ 1:1]. Thin-layer chromatography monitoring of all fractions obtained led to the accumulation of two combined fractions $\left[A_{1}\right.$ and $\left.A_{2}\right]$.

Removal of solvent mixture from each gave a white solid in both cases. Both white solids $\left[A_{1}\right.$ and $A_{2}$ ] were crystallized from pet.etherlacetone [1:1]. $A_{1}$ is white needles, m.p $216-220^{\circ} \mathrm{C}$ whereas $A_{2}$ is white crystals, m.p $188-190^{\circ} \mathrm{C}$.

The white grey solid was similarly chromatographedusing a glass column [ $80 \times 2 \mathrm{~cm}]$, packed with the same stationary phase in pet. ether. The column was carefully eluted first with

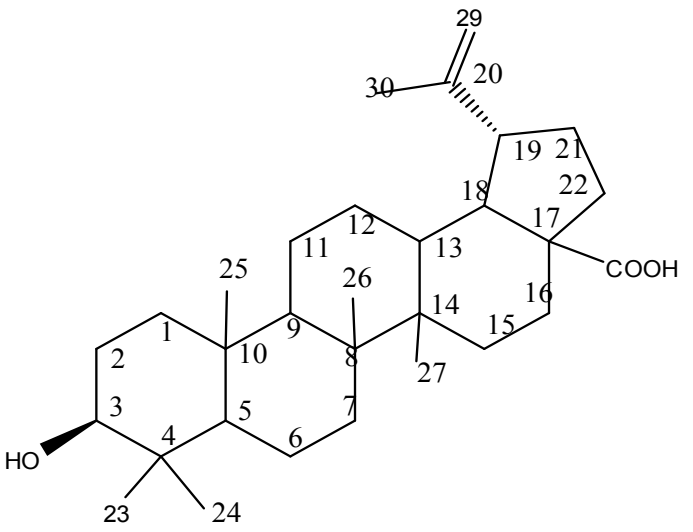

Scheme 3: Structure of compound 3 3-hydroxy20(29)-lupen-28-oic acid (betulinic acid) 
pet.etherlacetone [9:1] and finally with pet.etherlacetone [3:7] solvent mixtures. Thin-layer monitoring of all fractions obtained resulted in the accumulation of similar fractions in two combined fractions, $B_{1}$ and $B_{2}$. The two combined fractions $\left[B_{1}\right.$ and $B_{2}$ ] were perfectly dried separately, filtered and centrifuged.

When the solvent mixture was completely removed from each combined fraction, the resulting solids $B_{1}$ and $B_{2}$ were both separately crystallized from $\mathrm{DCM}$ and pet.etherlacetone[2:3], $\mathrm{B}_{1}$ gave white needles, m.p. $282-284^{\circ} \mathrm{C}$ whereas $\mathrm{B}_{2}$ gave a white solid with pleasant smell, m.p. $140-143^{\circ} \mathrm{C}$.

A glass column $[60 \times 2 \mathrm{~cm}]$ packed with the same silica gel in pet.ether was used for the separation of the components of the pale green sticky material $[D]$. The column was successively eluted with pet.etherlacetone[9:2] and [3:8]and finally with acetonelmethanol [1:1] and [1:9]. TLC monitoring of all fractions led to the accumulation of only one main combined fraction. Perfect drying of this combined fraction, filtration, centrifuge and complete removal of the solvent mixture, gave a white solid $\mathrm{D}_{2}$ which was crystallized from acetonel methanol [2:3], m.p. $250-252^{\circ} \mathrm{C}$.

\section{Spectroscopic Studies}

The isolated and purified components $\left[A_{1}, A_{2}, B_{1}, B_{2}\right.$ and $D_{2}$ ] were separately subjected to the following spectroscopic investigations using the relevant technique accompanied by the proper interpretation.

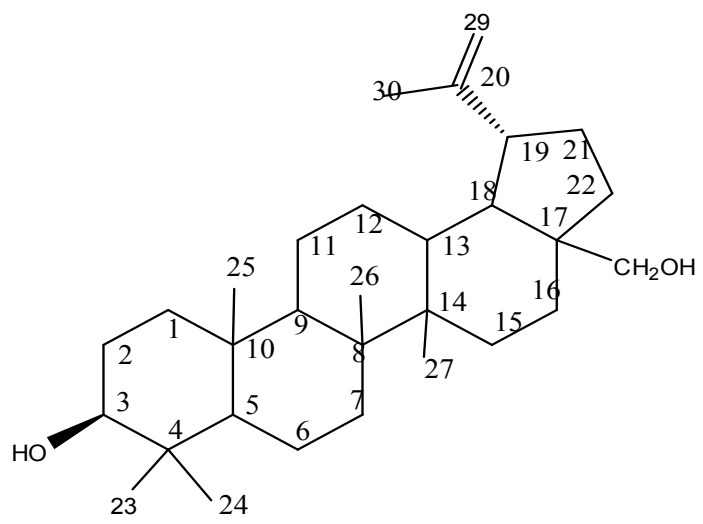

Scheme 4: Structure of compound 420(29)lupen-3,28-diol (betulin)

\section{Component $\mathrm{A}_{1}$}

UV $\lambda_{\text {max }}\left(\mathrm{CHCl}_{3}\right)$ 242nm.El-MS, M/Z. 426.3, $\mathrm{M}^{+}:$411.4, 315.3, 297.2, 218.2, 207.2, 189.2, 175.1, 147.1, 135.1, 121.1, 95.1, 81.1, 69.1, 55.0, 43.0.IR $v_{\text {max. }}(\mathrm{KBr})\left(\mathrm{cm}^{-1}\right), 3346(\mathrm{OH}), 2925(\mathrm{C}-\mathrm{H})$, $1452(\mathrm{C}=\mathrm{C}), 1381\left(\mathrm{CH}_{3}-\mathrm{C}\right), 1038(\mathrm{C}-\mathrm{O}), 880(\mathrm{C}-\mathrm{H})$.

${ }^{1} \mathrm{H}$ NMR (300MHZ, $\left.\left.\mathrm{CDCl}_{3}\right), \delta \mathrm{ppm}\right)$; shows the protons chemical shifts at $\mathrm{H} \delta 4.66(1 \mathrm{H}, \mathrm{d})$, at 4.54 $(1 \mathrm{H}, \mathrm{d})$, at $\mathrm{H} \delta 3.17(1 \mathrm{H}, \mathrm{dd})$, at $\mathrm{H} \delta 2.36(1 \mathrm{H}, \mathrm{td})$ and seven singlet methyl protons at $\mathrm{H} \delta 0.74,0.76,0.81$, $0.92,0.94,1.02$ and $1.67 .{ }^{1} \mathrm{H}-{ }^{13} \mathrm{C} \mathrm{HSQC}(400 \mathrm{MHZ}$, $\left.\mathrm{CDCl}_{3}\right) \mathrm{H} \delta(\mathrm{ppm})$; shows that the two protons at $\mathrm{H} \delta$ 4.66 and 4.54 are bonded to the same carbon atom at 109.0) $\mathrm{H} \delta$ ppm and the proton at $\mathrm{H} \delta 3.17$ is bonded to a carbon atom at 79.0$) \mathrm{ppm} .{ }^{1} \mathrm{H}-{ }^{1} \mathrm{H}$ COSY $(400 \mathrm{MHZ}$, $\left.\mathrm{CDCl}_{3}\right) \delta \mathrm{ppm}$ ); shows that $\mathrm{H}_{29}$ is correlated to $\mathrm{H}_{30}$. $\mathrm{H}_{29(a \& b)}$ are correlated to each other. $\mathrm{H}_{2}$ is correlated to $\mathrm{H}_{1}$ and $\mathrm{H}_{3}$ and $\mathrm{H}_{21}$ is correlated to $\mathrm{H}_{19}$ and $\mathrm{H}_{22} \cdot{ }^{1} \mathrm{H}-{ }^{13} \mathrm{C}$ HMBC $\left.\left(400 \mathrm{MHZ}, \mathrm{CDCl}_{3}\right) \delta \mathrm{ppm}\right)$; shows that $\mathrm{H}_{30}$ is correlated to $\mathrm{C}_{29,} \mathrm{C}_{20} \& \mathrm{C}_{19} \cdot \mathrm{H}_{27}$ is correlated to $\mathrm{C}_{13}, \mathrm{C}_{14}$ $\& \mathrm{C}_{15} \cdot \mathrm{H}_{26}$ is correlated to $\mathrm{C}_{9} \& \mathrm{C}_{14} \cdot \mathrm{H}_{25}$ is correlated to $\mathrm{C}_{1}, \mathrm{C}_{8}, \mathrm{C}_{9}, \mathrm{C}_{10} \& \mathrm{C}_{11} \cdot \mathrm{H}_{24}$ is correlated to $\mathrm{C}_{3,} \mathrm{C}_{4} \mathrm{C}_{5} \& \mathrm{C}_{10}$ $\mathrm{H}_{23}$ is correlated to $\mathrm{C}_{3} \mathrm{C}_{4} \& \mathrm{C}_{5}$ and $\mathrm{H}_{18}$ is correlated to $\mathrm{C}_{13,} \mathrm{C}_{17}, \mathrm{C}_{19}$ \& $\mathrm{C}_{20}{ }^{1}{ }^{1} \mathrm{H}-{ }^{1} \mathrm{H}$ NOESY $\left(400 \mathrm{MHZ}, \mathrm{CDCl}_{3}\right.$ ) ppm); shows correlation between $\mathrm{H}_{3}$ and $\mathrm{Me}_{(23224) \text {. }}$

\section{Component $\mathrm{A}_{2}$}

$U V \lambda_{\max }\left(\mathrm{CHCl}_{3}\right): 241.0 \mathrm{~nm}$. El-MS M/Z. 440.1, $\mathrm{M}^{+}: 426.1,411.1,379.1,315.1,207.1,189.1$, $175.1,161.1,135.1,121.0,95.1,81.1$ and 55.0. $I R v_{\max }(\mathrm{KBr})\left(\mathrm{cm}^{-1}\right): 3411(\mathrm{OH}), 2939(\mathrm{C}-\mathrm{H}), 1724$ $(\mathrm{C}=\mathrm{O}), 1641(\mathrm{C}=\mathrm{C}), 1453-1379\left(\mathrm{CH}_{3}-\mathrm{C}\right), 1039(\mathrm{C}-\mathrm{O})$ and $885(\mathrm{C}-\mathrm{H})$.

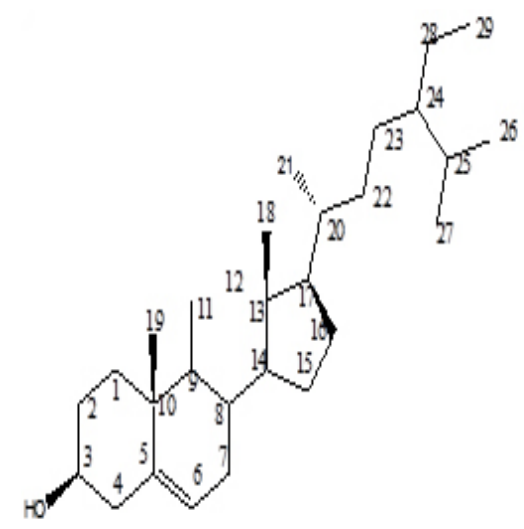

Scheme 5: Structure of compound 5 24-ethyl-5(6)-cholestene-3-ol ( $\beta$-sitosterol) 
${ }^{1} \mathrm{HNMR}\left(300 \mathrm{MHZ}, \mathrm{CDCl}_{3}\right)(\mathrm{ppm})$; shows the protons chemical shifts at $\delta \mathrm{H} 4.73(1 \mathrm{H}, \mathrm{s})$, at 4.61 $(1 \mathrm{H}, \mathrm{s})$, at $\delta \mathrm{H} 3.16(1 \mathrm{H}, \mathrm{dd})$, at $\delta \mathrm{H} 2.98(1 \mathrm{H}, \mathrm{m})$ and six singlet methyl protons at $0.73,0.86,0.83,0.94$, 0.95 and $\left.1.67 .{ }^{1} \mathrm{H}-{ }^{13} \mathrm{C} \mathrm{HSQC} \mathrm{(400MHZ,} \mathrm{CDCl}_{3}\right) \delta$ ppm); shows that the two protons at 4.73 and 4.61 are bonded to 110.0) carbon, the proton at $\delta \mathrm{H} 3.16$ is bonded to 77.2) carbon. ${ }^{1} \mathrm{H}-{ }^{1} \mathrm{H}$ COSY $(400 \mathrm{MHZ}$, $\mathrm{CDCl}_{3}$ ) ppm); shows that $\mathrm{H}_{29}$ is correlated to $\mathrm{H}_{30}$. $\mathrm{H}_{29(\mathrm{a} \& \mathrm{~b})}$ are correlated to each other. $\mathrm{H}_{9}$ is correlated to $\mathrm{H}_{11}$ and $\mathrm{H}_{21}$ is correlated to $\mathrm{H}_{19 \&} \mathrm{H}_{22 .}{ }^{1} \mathrm{H}-{ }^{13} \mathrm{C} \mathrm{HMBC}$ (400MHZ, $\mathrm{CDCl}_{3}$ ) ppm); shows that $\mathrm{H}_{30}$ is correlated to $\mathrm{C}_{29}, \mathrm{C}_{20}$ \& $\mathrm{C}_{18} . \mathrm{H}_{27}$ is correlated to $\mathrm{C}_{13}, \mathrm{C}_{14}$ \& $\mathrm{C}_{15}$. $\mathrm{H}_{26}$ is correlated to $\mathrm{C}_{9} \& \mathrm{C}_{14} . \mathrm{H}_{25}$ is correlated to $\mathrm{C}_{1}$, $\mathrm{C}_{8}, \mathrm{C}_{9} \& \mathrm{C}_{10} . \mathrm{H}_{24}$ is correlated to $\mathrm{C}_{3}, \mathrm{C}_{4}, \mathrm{C}_{5} \& \mathrm{C}_{10} . \mathrm{H}_{23}$ is correlated to $\mathrm{C}_{3}, \mathrm{C}_{4} \& \mathrm{C}_{5} . \mathrm{H}_{18}$ is correlated to $\mathrm{C}_{17}, \mathrm{C}_{20}$ \& $\mathrm{C}_{29 .}{ }^{1} \mathrm{H}-{ }^{-1} \mathrm{H}$ NOESY $\left.\left(400 \mathrm{MHZ}, \mathrm{CDCl}_{3}\right) \delta \mathrm{ppm}\right)$; shows the correlation between $\mathrm{H}_{3}$ and $\mathrm{Me}_{23 \& 24}$.

\section{Component $\mathrm{B}_{1}$}

$\left.\mathrm{UV} \lambda_{\text {max }} \mathrm{CHCl}_{3}\right) 209.0 \mathrm{~nm} . \mathrm{E} 1-\mathrm{MS} \mathrm{M} / \mathrm{Z} .456 .2$ $\mathrm{M}^{+}:$438.2, 423.2, 410.3, 395.2, 316.3, 302.3, 259.3, 248.3, 207.3, 189.3, 175.4, 161.3, 135.4, 95.4, 81.4, $69.4,55.4,43.4$.

IR $v_{\text {max. }}(\mathrm{KBr})\left(\mathrm{cm}^{-1}\right): 3450(\mathrm{OH}), 2937(\mathrm{C}-\mathrm{H})$, $1686(\mathrm{C}=\mathrm{O}), 1449(\mathrm{C}=\mathrm{C}), 1378\left(\mathrm{CH}_{3}-\mathrm{C}\right), 1189(\mathrm{C}-\mathrm{O})$, $883(\mathrm{C}-\mathrm{H}) .{ }^{1} \mathrm{H}$ NMR (400 MHZ, $\left.\mathrm{CDCl}_{3}\right) \delta(\mathrm{ppm})$; shows the chemical shifts of protons at $4.71(1 \mathrm{H}, \mathrm{s})$, at $4.58(1 \mathrm{H}, \mathrm{s})$, at $3.17(1 \mathrm{H}, \mathrm{dd})$, at $\delta \mathrm{H} 2.98(1 \mathrm{H}, \mathrm{m})$ and six singlet methyl protons at $\delta \mathrm{H} 0.73,0.80,0.92$, $0.94,0.96$ and 1.68 .

${ }^{1} \mathrm{H}-{ }^{13} \mathrm{C}$ HSQC of component $\mathrm{B}_{1}(400$ $\left.\mathrm{MHZ}, \mathrm{CDCl}_{3}\right) \delta(\mathrm{ppm})$; shows that the two protons at 4.71 and 4.58 are bonded to 110.0 ) carbon, the protonat 2.98 is bonded to 47.0) carbon and the proton at $3.17(1 \mathrm{H}, \mathrm{s})$ is bonded to 79.0$)$ carbon. ${ }^{1} \mathrm{H}$ ${ }^{1} \mathrm{H}$ COSY (400 $\left.\mathrm{MHZ}, \mathrm{CDCl}_{3}\right) \delta(\mathrm{ppm})$; shows that $\mathrm{H}_{29}$ is correlated to $\mathrm{H}_{30 .} \mathrm{H}_{29(a \& b)}$ are correlated to each other. $\mathrm{H}_{3}$ is correlated to $\mathrm{H}_{2} . \mathrm{H}_{21}$ is correlated to $\mathrm{H}_{19}$ ${ }_{8} \mathrm{H}_{22}$ and $\mathrm{H}_{15}$ is correlated to $\mathrm{H}_{16 .}{ }^{1} \mathrm{H}-{ }^{13} \mathrm{C} \mathrm{HMBC}(400$ $\left.\mathrm{MHZ}, \mathrm{CDCl}_{3}\right) \delta(\mathrm{ppm})$; shows that $\mathrm{H}_{30}$ is correlated to $\mathrm{C}_{29}, \mathrm{C}_{20} \& \mathrm{C}_{19} . \mathrm{H}_{27}$ is correlated to $\mathrm{C}_{13}, \mathrm{C}_{14} \& \mathrm{C}_{15} . \mathrm{H}_{26}$ is correlated to $\mathrm{C}_{9} \& \mathrm{C}_{14} . \mathrm{H}_{25}$ is correlated to $\mathrm{C}_{1}, \mathrm{C}_{8}$, $\mathrm{C}_{9} \& \mathrm{C}_{10} . \mathrm{H}_{24}$ is correlated to $\mathrm{C}_{3,} \mathrm{C}_{4,} \mathrm{C}_{5}, \mathrm{C}_{10}, \& \mathrm{C}_{23} \mathrm{H}_{23}$ is correlated to $\mathrm{C}_{3}, \mathrm{C}_{4} \mathrm{C}_{5}, \mathrm{C}_{6} \& \mathrm{C}_{24}$ and $\mathrm{H}_{18}$ is correlated to $\mathrm{C}_{13}, \mathrm{C}_{17}, \mathrm{C}_{20}, \mathrm{C}_{28}$ \& $\mathrm{C}_{29}$.
${ }^{1} \mathrm{H}-{ }^{-1} \mathrm{H}$ NOESY (400 MHZ, $\mathrm{CDCl}_{3}$ ) (ppm); shows the correlation between $\mathrm{H}_{16}$ and $\mathrm{H}_{22}$

\section{Component $\mathrm{B}_{2}$}

El-MS M/Z 414.3: $\mathrm{M}^{+396.3,381.3,351.2,}$ 329.2, 303.2, 289.2, 273.2, 255.2, 199.1, 173.1, 159.1, 145.0, 119.0, 107.0, 81.0, 69.0, 55.0.IR $v_{\max }$ $(\mathrm{KBr}) \mathrm{cm}^{-1} 3363(\mathrm{OH}), 2925(\mathrm{C}-\mathrm{H}), 1687.6(\mathrm{C}=\mathrm{O})$, $1458.0(\mathrm{C}=\mathrm{C}), 1377\left(\mathrm{CH}_{3}-\mathrm{C}\right), 1230.5(\mathrm{C}-\mathrm{O}), 1037.6$ (C-O) and 883.3 (C-H). ${ }^{1} \mathrm{H}$ NMR (300 MHZ, $\mathrm{CDCl}_{3}+$ $\left.\mathrm{CD}_{3} \mathrm{OD}\right) \mathrm{ppm}$ ); shows the protons chemical shifts at $\delta \mathrm{H} 5.23(1 \mathrm{H}, \mathrm{s})$, at $\delta \mathrm{H} 3.4(1 \mathrm{H}, \mathrm{d})$, at $\delta \mathrm{H} 3.16(1 \mathrm{H}, \mathrm{d})$, and six singlet methyl protons at $\delta \mathrm{H} 0.57,0.68,0.70$, $0.72,0.80$ and $0.91 .{ }^{13} \mathrm{C}$ NMR $\left(500 \mathrm{MHZ}, \mathrm{CDCl}_{3}+\right.$ $\mathrm{CD}_{3} \mathrm{OD}$ ) ppm), shows the ${ }^{13} \mathrm{C}$ chemical shifts of $\mathrm{C}_{3}$ at $\delta \mathrm{C}(70.5 \mathrm{ppm})$, of $\mathrm{C}_{5}(140.8 \mathrm{ppm})$ and of $\mathrm{C}_{6}$ at $\delta \mathrm{C}$ (121.7 ppm). ${ }^{1} \mathrm{H}-{ }^{13} \mathrm{C} \mathrm{HSQC}\left(500 \mathrm{MHZ} \mathrm{CDCl}_{3}+\right.$ $\left.\mathrm{CD}_{3} \mathrm{OD}\right) \delta(\mathrm{ppm})$, shows that the proton at 5.23 is bonded to 121.8 carbon and the two protons at 3.4 and at 3.16 are bonded to 70.5 carbon. ${ }^{1} \mathrm{H}-{ }^{1} \mathrm{H}$ COSY (500 MHZ, $\left.\mathrm{CDCl}_{3}+\mathrm{CD}_{3} \mathrm{OD}\right) \delta$ (ppm); shows that $\mathrm{H}_{6}$ is correlated to $\mathrm{H}_{7} . \mathrm{H}_{3(\mathrm{a} \& \mathrm{~b})}$ are correlated to each other, $\mathrm{H}_{3}$ is correlated to $\mathrm{H}_{2} \& \mathrm{H}_{4} . \mathrm{H}_{20}$ is correlated to $\mathrm{H}_{21} \& \mathrm{H}_{22}$, and $\mathrm{H}_{24}$ is correlated to $\mathrm{H}_{25}{ }^{1} \mathrm{H}-{ }^{13} \mathrm{C} \mathrm{HMBC}(500 \mathrm{MHZ}$, $\mathrm{CDCl}_{3}+\mathrm{CD}_{3} \mathrm{OD}$ ) ppm); shows that $\mathrm{H}_{28}$ is correlated to $\mathrm{C}_{23}, \mathrm{C}_{24}, \mathrm{C}_{25}$ \& $\mathrm{C}_{29} . \mathrm{H}_{21}$ is correlated to $\mathrm{C}_{17}, \mathrm{C}_{20}$ \& $\mathrm{C}_{22}$ $\mathrm{H}_{20}$ is correlated to $\mathrm{C}_{23} \& \mathrm{C}_{24} . \mathrm{H}_{19}$ is correlated to $\mathrm{C}_{1}, \mathrm{C}_{5}$ , $\mathrm{C}_{9} \& \mathrm{C}_{10} . \mathrm{H}_{18}$ is correlated to $\mathrm{C}_{11}, \mathrm{C}_{12}, \mathrm{C}_{13}, \mathrm{C}_{14,} \& \mathrm{C}_{17} . \mathrm{H}_{8}$ is correlated to $\mathrm{C}_{9} . \mathrm{H}_{7}$ is correlated to $\mathrm{C}_{9}, \mathrm{C}_{11}, \mathrm{C}_{13} \& \mathrm{C}_{14}$. $\mathrm{H}_{6}$ is correlated to $\mathrm{C}_{4} \mathrm{C}_{7}, \mathrm{C}_{8} \& \mathrm{C}_{10}$ and $\mathrm{H}_{4}$ is correlated to $\mathrm{C}_{1}, \mathrm{C}_{2}, \mathrm{C}_{3} \mathrm{C}_{5} \& \mathrm{C}_{6}{ }^{1} \mathrm{H}-{ }^{1} \mathrm{H}$ NOESY $\left(500 \mathrm{MHZ}, \mathrm{CDCl}_{3}\right.$ $\left.+\mathrm{CD}_{3} \mathrm{OD}\right) \delta(\mathrm{ppm})$; shows the correlation between $\mathrm{H}_{6}\left(\delta \mathrm{H} \mathrm{5.23)} \mathrm{H}_{4}(\delta \mathrm{H} 2.25)\right.$ and $\mathrm{H}_{7}(\delta \mathrm{H} 1.87)$, between $\mathrm{H}_{4-\mathrm{a}}$ 2.25)and $\mathrm{H}_{4-\mathrm{b}}$ 2.11), between $\mathrm{H}_{7}$ 1.87) and $\mathrm{H}_{8}$ $(\delta \mathrm{H} 1.35)$ and between $\mathrm{H}_{3}(\delta \mathrm{H} 3.4) \mathrm{H}_{4}(\delta \mathrm{H} 2.25)$ and $\mathrm{H}_{19}(\delta \mathrm{H} 0.91)$.

\section{Component $\mathrm{D}_{2}$}

UV $\lambda_{\text {max }}\left(\mathrm{CHCl}_{3}\right) 442.0 \mathrm{~nm}$. El-MS M/Z 442.3, $\mathrm{M}^{+}$: 424.3, 411.3, 302.2, 288.2, 248.1, 207.7, 189.1, 175.1, 147.1, 135.1, 95.0, 81.0, 55.0. IR $v_{\max }$ $(\mathrm{KBr})\left(\mathrm{cm}^{-1}\right): 3417.8(\mathrm{OH}), 2927.4(\mathrm{C}-\mathrm{H}), 1447.9$ $(\mathrm{C}=\mathrm{C}), 1378.3\left(\mathrm{CH}_{3}-\mathrm{C}\right), 1032.2(\mathrm{C}-\mathrm{O})$ and 882.9 (C-H). ${ }^{1} \mathrm{HNMR}\left(300 \mathrm{MHZ}, \mathrm{CDCl}_{3}\right) \delta$ (ppm); shows protons chemical shifts at $\delta \mathrm{H} 4.66(1 \mathrm{H}, \mathrm{s})$, at $\delta \mathrm{H} 4.71$ $(1 \mathrm{H}, \mathrm{s})$, at $\delta \mathrm{H} 3.17(1 \mathrm{H}, \mathrm{dd})$, three alcoholic protons at $3.78(1 \mathrm{H}, \mathrm{d}), 3.3(1 \mathrm{H}, \mathrm{d})$, one proton at $2.36(1 \mathrm{H}, \mathrm{dt})$ and six singlet methyl protons at $\delta \mathrm{H} 0.74,0.80,0.92$, $0.94,1.0$ and 1.68 . 
$\left.{ }^{1} \mathrm{H}-{ }^{13} \mathrm{C} \mathrm{HSQC} \mathrm{(400} \mathrm{MHZ,} \mathrm{CDCl}_{3}\right)$ (ppm); shows that the two protons at $4.66 \& 4.71$ are bonded to $(\delta C 110.0)$ ppm carbon, a proton at is bonded to $79.0 \mathrm{ppm}$ carbon and two protons at 3.3 \& 3.78 are bonded $(\delta \mathrm{C} 60.5 \mathrm{ppm})$ carbon.

${ }^{1} \mathrm{H}-{ }^{1} \mathrm{H}$ COSY (400 MHZ, $\left.\mathrm{CDCl}_{3}\right) \delta(\mathrm{ppm})$; shows that $\mathrm{H}_{29}$ is correlated to $\mathrm{H}_{30} \cdot \mathrm{H}_{29(\mathrm{a \& b})}$ are correlated to each other. $\mathrm{H}_{3}$ is correlated to $\mathrm{H}_{2} . \mathrm{H}_{21}$ is correlated to $\mathrm{H}_{19 \&} \mathrm{H}_{22}$ and $\mathrm{H}_{15}$ is correlated to $\mathrm{H}_{16 .}{ }^{1} \mathrm{H}$ $-{ }^{13} \mathrm{C} \mathrm{HMBC}\left(400 \mathrm{MHZ}, \mathrm{CDCl}_{3}\right) \delta(\mathrm{ppm})$; shows that $\mathrm{H}_{30}$ is correlated to $\mathrm{C}_{29}, \mathrm{C}_{20} \& \mathrm{C}_{19} . \mathrm{H}_{27}$ is correlated to $\mathrm{C}_{13}, \mathrm{C}_{14} \& \mathrm{C}_{15} . \mathrm{H}_{26}$ is correlated to $\mathrm{C}_{9} \& \mathrm{C}_{14} . \mathrm{H}_{25}$ is correlated to $\mathrm{C}_{1}, \mathrm{C}_{5}, \mathrm{C}_{9} \& \mathrm{C}_{10} . \mathrm{H}_{24}$ is correlated to $\mathrm{C}_{3}$, $\mathrm{C}_{4}, \mathrm{C}_{5} \& \mathrm{C}_{23} . \mathrm{H}_{23}$ is correlated to $\mathrm{C}_{3}, \mathrm{C}_{4}, \mathrm{C}_{5} \& \mathrm{C}_{24}$, and $\mathrm{H}_{19}$ is correlated to $\mathrm{C}_{18}, \mathrm{C}_{20}, \mathrm{C}_{21}, \mathrm{C}_{29}$ \& $\mathrm{C}_{30}$

${ }^{1} \mathrm{H}-{ }^{1} \mathrm{H}$ NOESY (400 $\left.\mathrm{MHZ}, \mathrm{CDCl}_{3}\right) \delta(\mathrm{ppm})$; shows a correlation between $\mathrm{H}_{3}$ 3.17) and $\mathrm{Me}_{23 \& 24}$ 0.94 \& 0.74 ) and between $\mathrm{H}_{18}$ 1.6) and $\mathrm{H}_{28(\text { a\&b }} 3.3$ \&3.78).

\section{RESULTS AND DISCUSSION}

Z. spina christi family Rhamnaceae is widely distributed in the tropical and subtropical regions of the World. The tree is a multipurpose plant,widely used in folk medicine ${ }^{21}$ and its delicious fruit ${ }^{22}$ has a limited commercial value.

The fine powder of the shade-dried root bark was exhaustively extracted with aqueous ethanol. The dry crude extract [ $28 \%$ mean yield], was carefully and patiently subjected to intensive and extensive fractionation using column chromatography.

Subsequent monitoring with thin-layer chromatography and refractionation of the resulting combined similar fractions led to the isolation of five components referred to as $A_{1}, A_{2}, B_{1}, B_{2}$ and $D_{2}$. Which were vigorously purified.

Characterization and structure elucidation of the isolated and purified above components were based on different spectroscopic data including 1D and 2D NMR spectroscopy.

Careful study of the proton nuclear magnetic resonance spectroscopic data for each of the components $A_{1}, A_{2}, B_{1}, B_{2}$ and $D_{2}$ revealed that these components have triterpene skeletons. The HSQC and COSY spectroscopic investigations showed that the above triterpene skeletons are of lupane-type.

Proper interpretation of the infrared analytical spectroscopy and the Hetronuclear Multiple bond Correlation Spectroscopy led to the possible suggestions that the structures of the above components might be: 20(29)-lupen-3-ol, 20(29)lupen-3-ol-28-al, 20(29)-lupen-3-ol-28-oic acid, 20(29)-Iupen-3,28-diol respectively. Their NOESY spectroscopic correlations data confidently confirm the above suggested structures. Identification of these components was based on comparing their spectroscopic data with literature data given for triterpenes isolated from plant materials. These components are lupeol, betulinaldehyde, betulinic acid and betulin respectively.

Study of the ${ }^{1} \mathrm{HNMR}, \mathrm{HSQC}$ and COSY of spectroscopic data indicate that component $B_{2}$ is Sterol. Careful interpretation of the infrared resonance spectra and the $\mathrm{HMBC}$ correlation spectra showed that the structure of $\mathrm{B}_{2}$ might be 24ethyl-5(6)-cholestene-3-ol. The NOESY correlation spectra of $B_{2}$ confirmed the determined structure and comparison with literature data given for steroids isolated from plant species proved that $B_{2}$ is â-sitosterol. Thus all the isolated components are known compounds previously obtained from other plants.

To the best of the author knowledge, lupeol, betulinaldehyde, betulin and $\beta$-sitosterol were isolated for the first time from the root bark of $Z$. spina Christi grown in Sudan.

\section{ACKNOWLEDGEMENT}

We are highly indebted to Prof. Mohammed Igbal Choudhary and Dr. Achyut Adhikari and all members of Hussin Ebrahim Jamal (HEJ) research institute of chemistry, International Center for Chemical and Biological Sciences (ICCBS), University of Karachi, Karachi-Pakistan, for their indispensible help and constructive advices. 


\section{REFERENCES}

1. Sofowora, Medicinal plants and Traditional Medicine in Africa, John Wiley and Sons limited. (1982)

2. Abdel wahhab, M. A.; Omara, E. A; Abdel Gali, M. M.; Hassan, N. S.; Nada, S. A.; Saeed, A.; Elsayed M. M. African Journal of Traditional, Complementary and Alternative Medicines. 2007, 4, 248-256.

3. Sofowora, A. Medicinal Plants and Traditional Medicines in Africa. Chichester John, Willey \& Sons New York; 256. (1993).

4. Steven, M.; Russell, J. C.; Molyneux, J.; Bioactive Natural Components of the petroleum ether fraction from the root bark ethanol extract using GClMS I Products Detection, Isolation and Structural Determination Taylor \& Francis, USA, (2008).

5. New man, D.J; Cragg G.M. Journal of Natural Products. 2007, 70, 461-477.

6. Natural Products Reports, New York. 1985, 26, 299- 306.

7. International Journal of Biochemical and Pharmaceutical sciences. Global Science Books (2009).

8. Basa Vara, J.a.; H. S. J.Pharm. Science and Res., 2010, 3, $13-15$.

9. Agar Wal, R. B. ; and Rangari, V. D. Indian Journal of Phamacology. 2003, 35,284 $-287$.

10. Indian Journal of Pharmaceutical Sciences. 1988, 50,124-125,.

11. Slinivasan, T. BioOrganic and Medicinal Chemistry Letters. 2002, 12, 2803 -2806.

12. Shah, A. H; Pandey, V.B ; Eckhard, G. ,
Tschesche, R. J. Nat. Prod. 1985 48, 555558.

13. Jan Sarek; J. Med. Chemistry. 2003, 71, 5402 $-5415$.

14. Shah ,A.H. ; Ageel, A.M.; Tarig, M.; Mossa, J.S.; Al-Yahya, M.A. Chemical constituents of the stem bark of Zizyphus spina Christi. Fitoterapia. 1986 ,57,452-454,.

15. Anthony, C.; Dweck, F.L.S . Personal Care Magazine . 2005, 2-5.

16. Adzu, B.; Haruna, A.K.; Ilyas M. ; Pateh, U.U; Tarfa, F.D.; Chindo, B.A ; Gamaniel, A .S .Journal of Pharmacy and Nutrition Sciences. 2011, 1, 48 -53.

17. Hongyan Liu; Synthesis of Betulinic acid from Betulin; M.Sc of science; Natural library of Canada; Acquisitions and Bibiographic Servicas; 2001.

18. Yunusoy, M. S. Russion Plant, 6, pp. CODEN, RUXX, 67, RU 2270202 C1 20060220.

19. EL Znhmer, D. V. XLI 2Q. Drugs. 2007, 7,359 $-373$.

20. Fujioka T.; Kashiwada Y.; Kilkuskie R. E.; Consentino L. M.; Ballas L. M.; Jiang J. B.; Janzen W. P. Journal of Natural Products. 1994, 57, $243-247$.

21. www/Natural News. Com., Natural health, Natural living, Natural News.

22. Sudhersan C.; Hussain J. Turk J Bot. 2003, 27,167-171.

23. Steele, J. A. JOC. 1963, 28, 571-572.

24. Mastomato, T. Phytochemistry. 1983, 22,2622-24.

25. Aizawa, K. Org Mass Spectrom. 1974, 9, 470 -79 . 